\title{
Depletive Water Balance and High Vulnerability Due to Conflicts over Access and Rights
}

\author{
Jawad Hasan Shoqeir \\ Earth and Environmental Sciences Department, Al-Quds University, Jerusalem, Palestine \\ Email: jhassan@science.alquds.edu
}

Received 31 March 2014; revised 28 April 2014; accepted 24 May 2014

Copyright (C) 2014 by author and Scientific Research Publishing Inc.

This work is licensed under the Creative Commons Attribution International License (CC BY).

http://creativecommons.org/licenses/by/4.0/

(c) (i) Open Access

\begin{abstract}
Sustainable water supply problem becomes strategic when inelastic demand levels are overhauling maximum available supplies. The situation is more acute when the groundwater recharge area is heavily populated, consist of urban, industrial and agricultural areas and above all have typical karstic morphology and extensive regions of thin or null soil cover. During winter season the infiltrated water mixed with the wastewater leaking from poorly designed cesspits and wastewater overflow from the treatment plants of the adjacent settlements. Currently, most of the recharge area is disturbed due to the ongoing urban development in Beitar Elite and Tzur Hadassah in conjunction with the planned Security Fence (apartheid wall) threatens to extend over $\sim 70 \%$ of the aquifer recharge area. Such massive destruction in a small watershed leads to considerable decrease in springs discharge and could completely dry-out the springs at the upper part of the valley. The aim of this research is to improve understanding of the hydrologic processes controlling water quantity and quality of springs discharging small $\left(<1 \mathrm{E} 6 \mathrm{~m}^{3} / \mathrm{yr}\right)$ basin in the mountain aquifer.
\end{abstract}

\section{Keywords}

Perched Aquifers, Mountain Aquifer, Surface Runoff, Urban Development, Fragile Environment

\section{Introduction}

Groundwater is a natural drinking water resource often subjected to severe human impact [1] where strategies are required to preserve optimum groundwater quality, and so management of this vital natural resource has become a worldwide priority [2]. Groundwater from karst aquifers is among the most important resources of drinking water supply of the worldwide population. In Europe, carbonate terrains occupy 35\% of the land sur- 
face and in some countries; karst water contributes $50 \%$ to the total drinking water supply. In some regions, it is the only available freshwater resource [3].

In Palestine, the carbonate Mountain Aquifer is the largest quantity and with the best quality fresh water resource, providing an average of 600 million cubic meters (MCM) of fresh water per year [4] for domestic and agricultural needs. Springs draining smaller perched basin in higher elevations in the mountain aquifer outcrop area (Sarar Al-janobi catchment in Bethlehem) produce smaller quantities of water relatively to down gradient springs that drain the main aquifer [5], therefore in most cases they are not connected to modern water distribution system, nevertheless due to the scarcity of water in recent years these quantities can be significant. These springs are often vulnerable to anthropogenic contamination because of the short residence time of water in discrete fast conduits, and many residential areas in the recharge zones.

The fresh groundwater in the aquifers of Serar Al-janobi catchment area is the main source of drinking water and agricultural activity for the Palestinians, and therefore understanding the hydrology and the geochemistry of this system is of major interest. In addition, this research is necessary for better understanding the negative impact of the planned and on-going urban development of adjacent settlement (Tzur Haddasa and Beitar Elite) within Wadi Fuqeen valley (Figure 1), since the groundwater flow rates, spring discharge and the chemistry is altered.

The aim of this research is to improve understanding of the hydrologic processes controlling water quantity and quality of springs discharging small $\left(<1 \mathrm{E} 6 \mathrm{~m}^{3} / \mathrm{yr}\right)$ basin in the mountain aquifer. More specifically, the characterization of springs discharging agriculture dominated small basin $\left(\sim 8 \mathrm{~km}^{2}\right)$ springs which represent local and regional water resources in the western slopes of the mountain aquifer.

\section{Methodology}

\subsection{Study Area}

Serar Al-Janobi catchment covers an area of $25 \mathrm{~km}^{2}$, located to the west of Bethlehem Governorate, which represents the southern part of the west Bank (Figure 1). From the other hand the study area is part of the Auija Tamaseeh sub basin, which originally part of western Basin of the Mountain Aquifer [6].

The springs of the Serar Al-Janobi and its sub catchments especially the springs within Wadi Fuqeen belong to perched karstic aquifers. Wadi Fuqeen village is located on the top of the eastern trails of Hebron mountains, $16 \mathrm{~km}$ to the south eastern part of Jerusalem, and $12 \mathrm{~km}$ to the south east of Bethlehem. The stratigraphy of the West Bank includes several formations; each formation has different properties in rock type and aquifer potential. The lithology of the trails and slops along Wadi Fuqeen and the surrounding area are Limestone, Dolomite, Chalk and Marl, comprising Yatta, Hebron and Bethlehem formation. These rocks determine the ability of formations to be aquifer or aquiqlude (Figure 2). Yatta formation is considered as an aquiclude while Hebron and Bethlehem formation are considered as aquifers of the Turonian-Cenomanian age. The Alluvial formation is of Holocene (Quaternary) age, and it is considered as a good shallow aquifer [6] [7].

\subsection{Data Collection}

Within a closed basin of known area over a selected time interval, field work and field surveys were basic modules in every aspect of this study, especially to confirm the data collected during the interviews, to identify and mapping the existing water resources, water sampling and measurement of waste water flow rate.

Global Positioning System (GPS) was compiled to confirm the manually drawn water divide, incorporating the drainage system and to determine the coordinates and elevations of the wells and springs. The drainage divide of Wadi Fuqeen drainage basin was delineated using the elevations contours and identified point elevations on a topographic map of 1:50000 scale.

Direct measurements were made at each site with a WTW field set of probes, giving readings for temperature, electrical conductivity (EC), dissolved oxygen (DO) and $\mathrm{pH}$. In the laboratory of Al-Quds Univeersity, the samples were analyzed according to the standard methods for the examination of water and wastewater (American Public Health Association 1995) for the major ions and for the total and fecal coliform bacteria.

Graphical and statistical methodologies were used to classify the water samples into homogeneous groups. These methodologies include Piper and Durov diagrams using AquaChem software. Based on Fetter Equation [8] spring discharge and recession curve can be calculated as: 


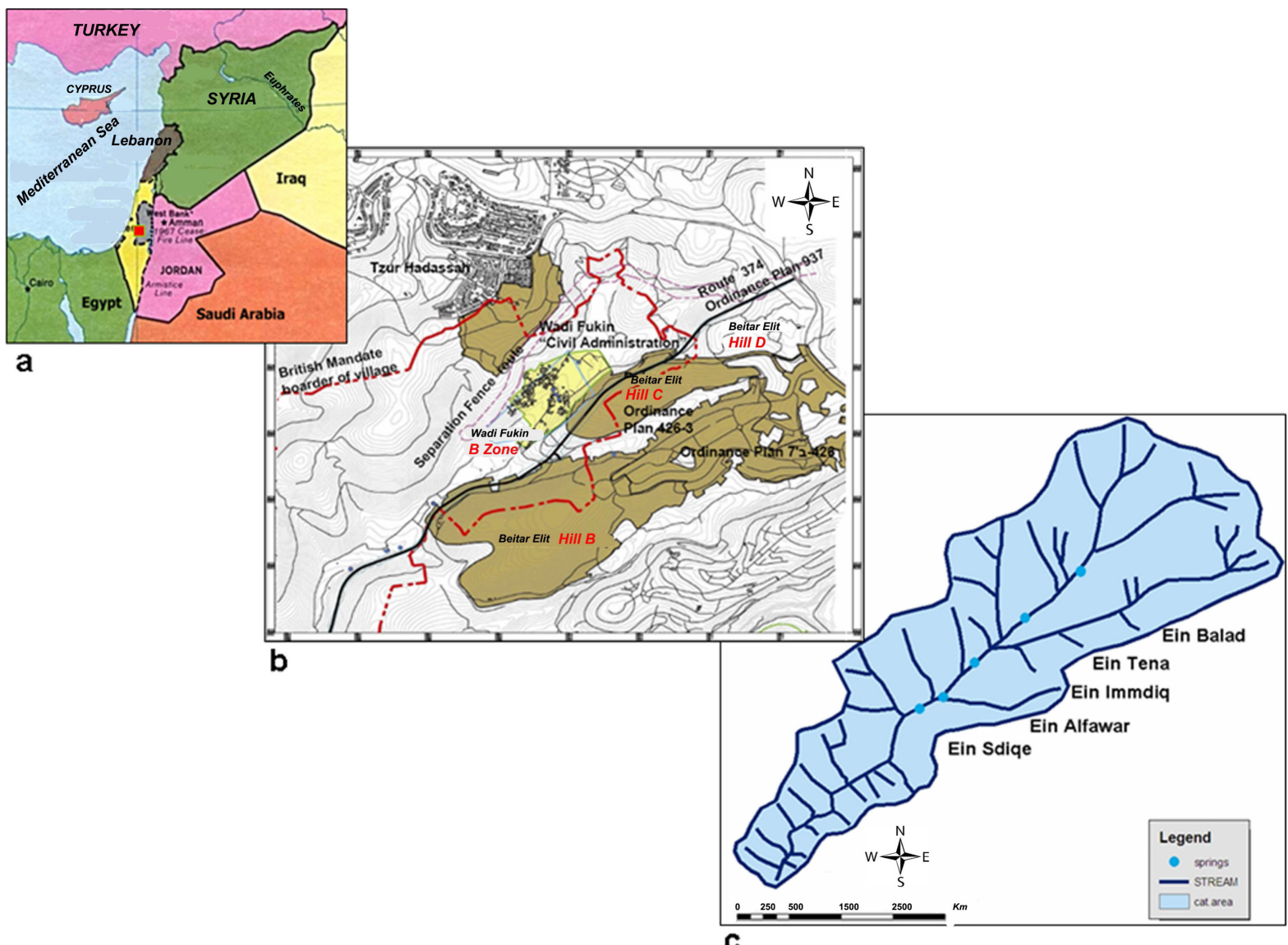

Figure 1. a) Map showing the study area in West Bank, Palestine. b) A map showing the Wadi boundaries labeled with red line indicating the British mandate boarders for the year 1948. c) The catchment of Wadi Fuqeen springs group map showing the names and springs location.

\begin{tabular}{|c|c|c|c|}
\hline Upper Bethlehem Fm & 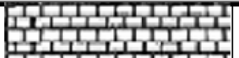 & Upper Cenomanian & Aquifer \\
\hline Hebron Fm & & Lower Cenomanian & Aquifer \\
\hline Yatta Fm & & Lower Cenomanian & Aquiclude \\
\hline
\end{tabular}

\begin{tabular}{|ll|} 
Lithology Legend \\
Exy & Limestone \\
\hline Darl & Dolomite \\
\hline
\end{tabular}

Figure 2. Generalized geological columnar section indicating the aquiferial characteristics of the various formations in the study area.

$$
Q=Q^{\circ} e^{-\lambda t}
$$

where:

$Q=$ discharge at end of recession $(\mathrm{L} / \mathrm{s})$

$Q^{\circ}=$ initial discharge $(\mathrm{L} / \mathrm{s})$

$\lambda=$ recession coefficient

$t=$ duration of the recession time (d)

According to Komac [9] the volume of water stored in one layer aquifer can be calculated as:

$$
V=\left(Q^{\circ}-Q^{t}\right) / \lambda
$$

where:

$V=$ volume of stored water 


$$
\begin{aligned}
& Q=\text { discharge }\left(\mathrm{m}^{3} / \mathrm{d}\right) \\
& \lambda=\text { aquifer physical characteristics } \\
& t=\text { duration time }(\mathrm{d})
\end{aligned}
$$

\section{Results}

The water balance for Wadi Fuqeen springs shows discharge and recession coefficient (storage coefficient) values similar to perched, unconfined aquifers responding to seasonal variability. According to Fetter and Komac equations [8] [9] the values of storage coefficient and storage volume is as Ein Balad $\left(\lambda=3.9 \times 10^{-3}, V=5998\right.$ $\left.\mathrm{m}^{3}\right)$, Ein Tena $\left(\lambda=3.0 \times 10^{-3}, V=1667 \mathrm{~m}^{3}\right)$, Immdiq $\left(\lambda=3.5 \times 10^{-3}, V=1600 \mathrm{~m}^{3}\right)$, Al-Fawar $\left(\lambda=3.0 \times 10^{-3}, V\right.$ $\left.=1720 \mathrm{~m}^{3}\right)$ and Ein Sdiqe $\left(\lambda=3.2 \times 10^{-3}, V=1819 \mathrm{~m}^{3}\right)$ with recharging area $2.5 \mathrm{~km}^{2}, 2.7 \mathrm{~km}^{2}, 4.9 \mathrm{~km}^{2}, 2.5$ $\mathrm{km}^{2}$ and $6.1 \mathrm{~km}^{2}$ respectively. The spring's aquifer is considered as perched aquifer and is completely separated from regional aquifers in the area; this can be seen from the low $\lambda$ values $\left(<4 \times 10^{-3}\right)$ indicating flow system with low connected rocks (porous). The discharge for each spring is variable depending on its emergence, elevation and its location. Ein Balad and Immdiq emerge from Hebron formation (Lower Cenomanian), Ein Tena and Sdiqe emerge from alluvial formation (Figure 3).

Duruv diagram (Figure 4(a)) show that the groundwater sample of Ein Immdiq spring plots in field (2), while the samples of Ein Balad, Ein Tena plots in field (5) indicating mixing with wastewater accompanied with simple dissolution of carbonate minerals. The springs Ein Alfawar, Ein Sdiqe plots in field (1) indicating ion exchange. On Piper diagram (Figure 4(b)) the ground water samples plots in (a, b and d) area of normal earth alkaline water with prevailing bicarbonate and with bicarbonate-sulfate or chloride. Relatively high concentration of chloride and sulfate is as a result due to mixing with other water resource coming from washing the contaminants from animals and agricultural purposes as well as wastewater dumped to the adjacent Wadis. The results of Fecal Coliform > $1000 \mathrm{CFU} / 100 \mathrm{ml}$ confirm wastewater intrusion.

\section{Discussion}

The results reviles that Wadi Fuqeen is vulnerable due to its hydrological sitting where soil cover is very thin, Groundwater is shallow and it is exposed to high risk of pollution manly due to effluent discharge from the adjacent settlements where biological analysis confirm wastewater intrusion. Wadi Fuqeen has a very small recharge area $\left(18.5 \mathrm{~km}^{2}\right)$, with local and small underground catchment area that feeds the springs. Therefore it is considered highly vulnerable to land use modifications in the vicinity of the valley. The illegal intensive development and construction in the area over the last 20 years has damaged the Wadi due to the urban development within the recharge area of the springs, increasing surface runoff. As a result this urban development decreased the infiltration of rain into the underground catchment due to the increase of the sealed surfaces. The total planned area and the ongoing construction according the following plans, Plan 426/3/hill C, Plan426/7/hill B1, Plan 426/8/hill B2, Plan 520/Sansan hill B and Plan apartheid wall 937. All plans exceed $3 \mathrm{~km}^{2}$ and constitute more than $40 \%$ of the entire hill slope area within Wadi Fuqeen recharge zone (Figure 5). These plans don't include the natural growth of the village itself. The continues construction of Beitar Elit settlement to the east and the expansion of TzurHadassah settlement to the west (Figure 5) have harmed the valley's local aquifer and damaged the area's reinforcement slopes leading to a major decrease in the springs discharge and a complete destruction of three springs in the Wadi, not only but also it lead to Wadi soil erosion.

\section{Conclusions}

The rain water is the only source of groundwater recharge. Any reduction in the discharge of the springs will decrease the total area which can be efficiently irrigated. Furthermore, the quality of the urban runoff as well as expected spills from the sewage system of Beitar Elite, mixing with the wastewater leaking from the poorly designed cesspits, infiltration leachat from washing the piles of animals dung, fertilizers by the rainfall in winter are responsible for introducing contaminants into the hydrological system. Currently, most of the recharge area is fully disturbed due to the unsustainable development of Betar Illit and Tzur Hadassah settlements.

In order to conserve and protect the fragile environment, we need to prohibit any farther illegal urban development along hill slopes (hill B, C and Sansan B). The planed apartheid wall within Wadi Fuqeen should be cancelled. Wastewater treatment and reuse, water harvesting and artificial recharge should be taken in consideration. 


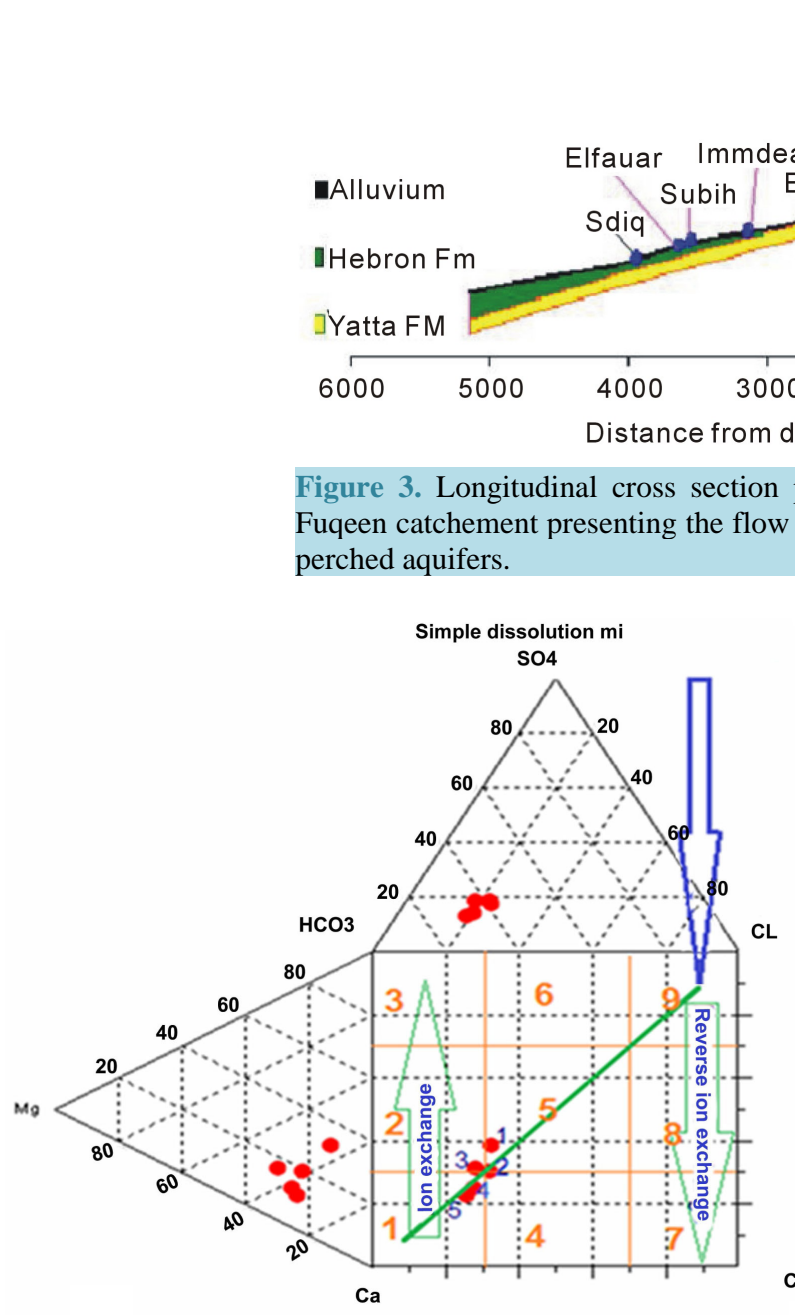

(a)

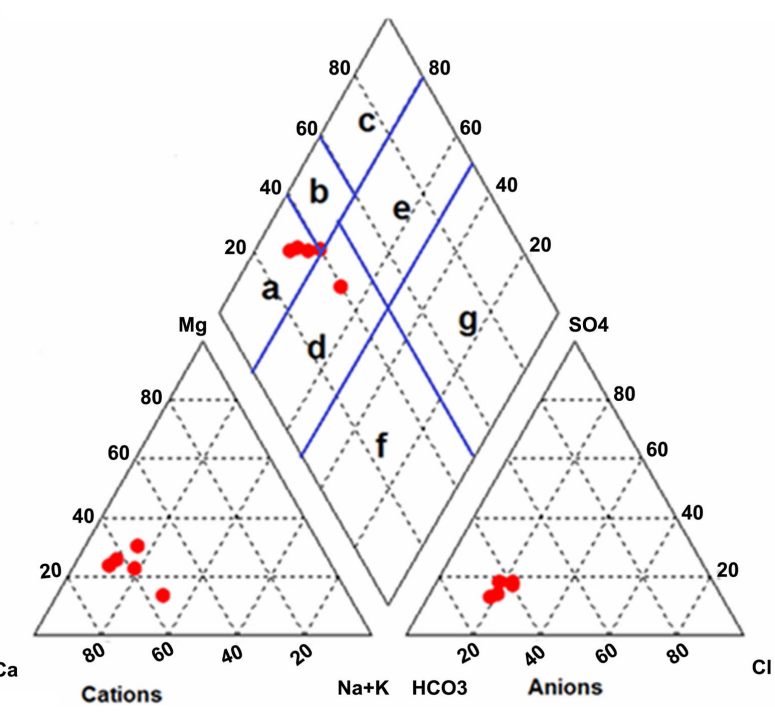

(b)

Figure 4. Hydrological data interpretation using aquachem. a) Durove diagram of groundwater samples, b) piper diagram for groundwater samples.
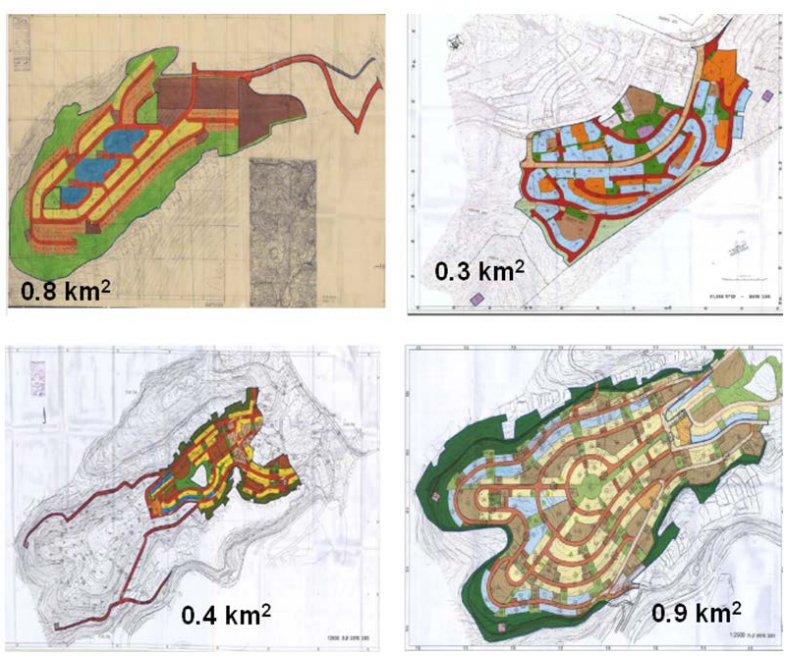

Figure 5. Planned and ongoing illegal urban development of the two settlements within Wadi Fuqeen hill slops. 


\section{Acknowledgements}

We gratefully acknowledge the financial and logistic support provided by Qumran Eco consulting and for SMART project at KIT University which is funded by the German Federal Ministry of Education and Research (BMBF). Special regards to the staff of Soil Hydrology Lab at AQU for their support. Special thanks also go to the reviewers for their efforts for improving and finalizing the outcome manuscript.

\section{References}

[1] Falkenmark, M. (2013) Growing Water Scarcity in Agriculture: Future Challenge to Global Water Security. Philosophical Transactions of the Royal Society A Mathematical, Physical \& Engineering Sciences, 371, 20120410.

[2] Drew, D. and Hötzl, H. (1999) Conservation of Karst Terrains and Karst Water. International Contributions to Hydrogeology (IAH), Balkema, Rotterdam, 322p.

[3] Office for Official Publications of the European Communities (1995) Cost Action 65: Hydrogeological Aspects of Groundwater Protection in Karstic Areas: Final Report. Office for Official Publications of the European Communities, Brussels.

[4] Israel, H.So. (2005) Development and Status of Israel's Water Resources as of Fall 2004. Hydrological Service of Israel Report from Office of National Infrastructure.

[5] Shoqeir, J. (2014) Tracing Groundwater in Karstic Aquifer: IWRM Components Implications and Challenges. LAP Lambert Academic Publishing, AV Akademikerverlag GmbH \& Co. KG., Osnabrück, 264p.

[6] El-Fadel, M., Quba’a, R., El-Hougeiri, N., Hashisho, Z. and Jamali, D. (2001) The Israeli Palestinian Mountain Aquifer: A Case Study in Ground Water Conflict Resolution. Journal of Natural Resources \& Life Sciences Education, 30, 50-61.

[7] Qannam, Z. (2003) A Hydrogeological, Hydrochemical and Environmental Study in Wadi Al Arroub Drainage Basin, Inst. für Geologie, South West Bank, Palestine.

[8] Fetter, C.W. (2001) Applied Hydrogeology. Prentice Hall, Upper Saddle River, NJ, xvii, 598p.

[9] Komac, B. (2001) The Karst Springs of the Kanin Massif. Acta Geographica, 41, 12. 
Scientific Research Publishing (SCIRP) is one of the largest Open Access journal publishers. It is currently publishing more than 200 open access, online, peer-reviewed journals covering a wide range of academic disciplines. SCIRP serves the worldwide academic communities and contributes to the progress and application of science with its publication.

Other selected journals from SCIRP are listed as below. Submit your manuscript to us via either submit@scirp.org or Online Submission Portal.
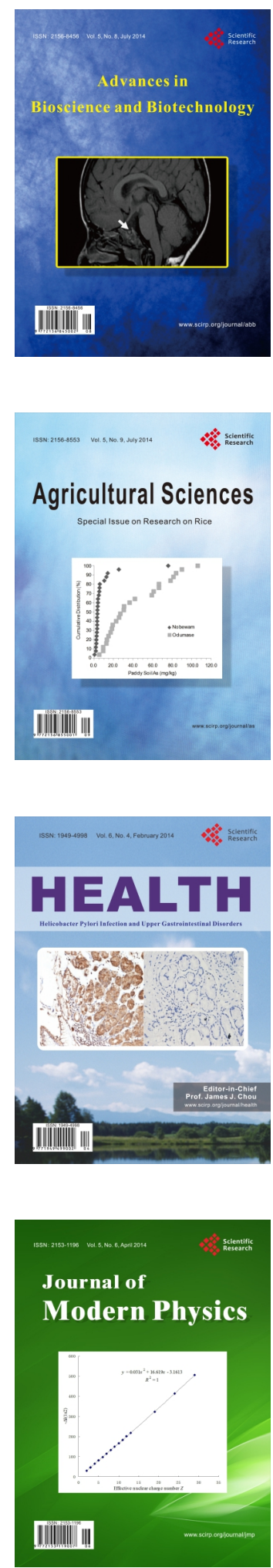
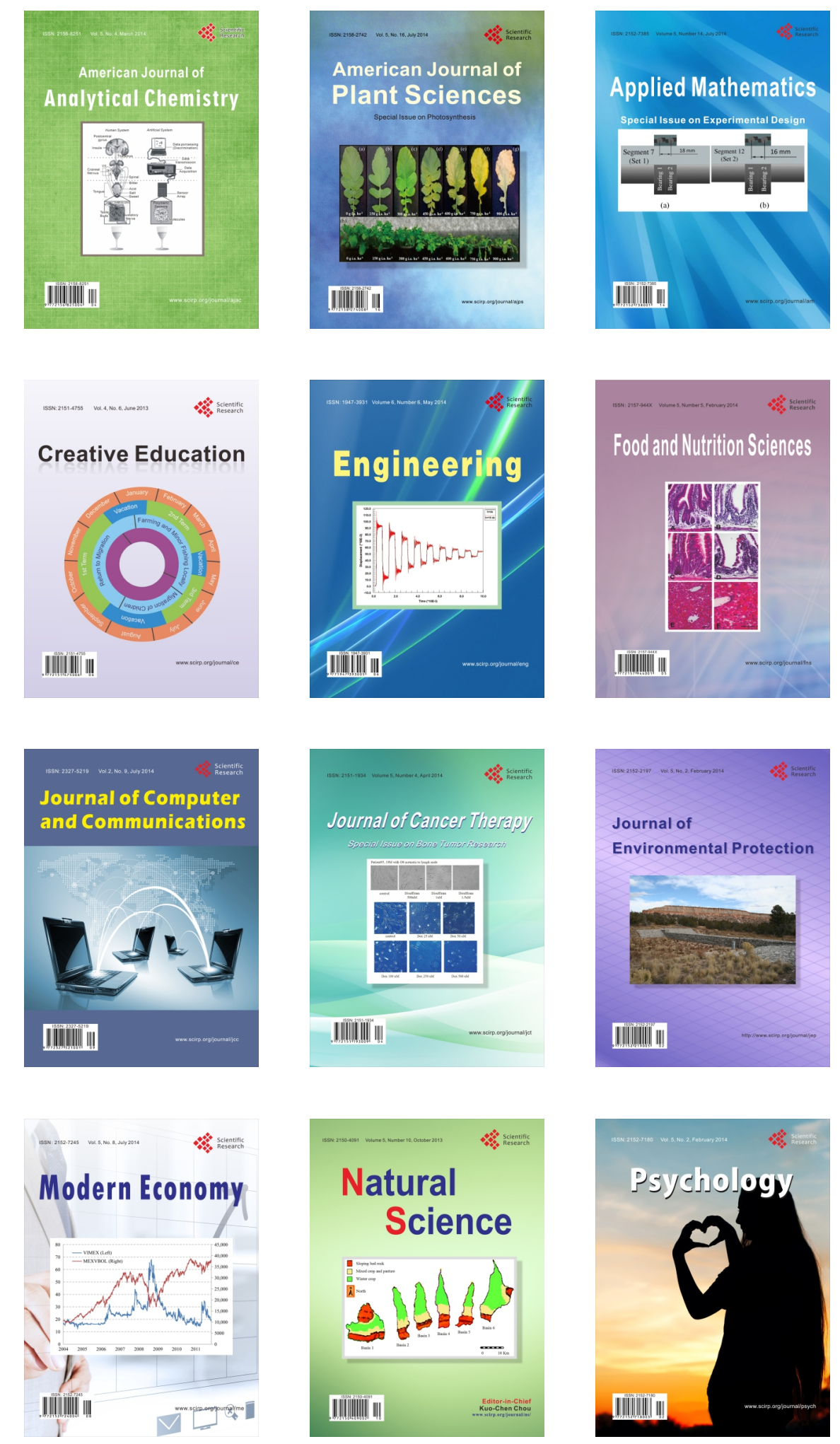